\title{
East and Central Europe Stock Exchange Markets in the ages of globalization
}

\author{
Stanislaw Kaszuba
}

\begin{abstract}
Background: Global crisis situation caused many unpredicted causes. Huge governmental financial aid, $60 \%-70 \%$ stock exchange indices reduction are only few examples. Central Europe is a part of emerging markets. Warsaw Stock Exchange is the largest Stock Exchange Market in this region. Objective: The aim of this article is to present a main view of Polish capital market development. It shows advantages from creation Alternative Stock Exchange Market NewConnect. The aim of this article is to present the phenomenon of Warsaw Stock Exchange as a leader of emerging markets of Central and Eastern Europe region. Methods: Author makes an analysis between East and Central European Stock Exchange Markets with a special view on alternative investment markets. Moreover briefly describe Polish capital market problems triggered by global financial crisis. The article shows perspectives of future growth and describes the impact of global financial crisis into Warsaw Stock Exchange.Results: Warsaw Stock Exchange makes possible gaining vital capital to the companies for their future growth, especially on NewConnect market. It was a fastest growing market in 2008. Polish capital market is a very good alternative, if compared with European Stock Exchanges. However, limited knowledge of investors and high correlation with global capital markets are making strong influence in future Polish Stock Market development.
\end{abstract}

Index Terms-emerging markets, stock exchange, Warsaw Stock Exchange, Wiener Börse AG,

\section{INTRODUCTION}

Global financial crisis, which had its start took place in United States of America in 2007, gave a big impact in almost every element of global economy. Most of financial markets on every continent did note huge indices reduction. In the beginning, the crisis was named only as "financial" one, but nowadays it is sure that it should be named as a global capitalistic economy crisis. No restrictions in creating toxic financial products, no control from the government, enormous bonuses for traders and CEO's in largest financial institutions (rarely lower than 7-digit amount) had to cause actual situation. September Pittsburgh meeting of G20 is showing that every country is seriously worried about future economy style. France and Germany proposed the limitations in remuneration of CEO's and main traders. It is very important that the world must stop looking after short-term speculative profits. With no long-term view and strategy world's economy will stay in the same situation of crisis for many months, even years.

Polish Warsaw Stock Exchange (WSE) is the largest Stock

Email:stanislaw.kaszuba@gmail.com,+48-600676787
Exchange in Central and Eastern Europe region. Scandinavian OMX group is concentrating three Stock Exchanges from Stockholm, Helsinki and Copenhagen. The first natural concurrent for WSE are Stock Exchanges in Prague (Czech Republic) and Austrian Wiener Börse AG. Hungarian Stock Exchange in Budapest and Romanian Bursa de Valori Bucaresti also plays a big role in Central and Eastern Europe capital market. Besides Stock Exchange in Wien all of the above are the part of global emerging markets. This term was born in 1980s for countries which are considered to be in a transitional phase between developing and developed status. In recent years, the most important part of emerging markets were the BRIC countries (Brazil, Russia, India and Chile). These countries do not share any strategies or economy agendas, but many analysts and experts of economy is believing that they may be compared as one big concurrent market. The Big Emerging Market (BEM) was defined by British FTSE experts and consists from Brazil, China, Egypt, India, Indonesia, Mexico, Philippines, Poland, Russia, South Africa, South Korea and Turkey. Hungary and Czech Republic are part of Morgan Stanley Capital International (MSCI) list of emerging countries.

\section{Polish Warsaw Stock Exchange (WSE)}

\section{A. History}

The first Sock Exchange in Poland was founded in 1817 and was working until 1939. The trade was consisting from bonds and bills of exchange. Securities first listings took place in second half of XIX century. In 1938 big amount of 130 securities were listed. Due to World War II and communism Polish Stock Exchange was closed until 1991. In 2000 new electronic system WARSET was implemented in WSE. In 2007 WSE had introduced an alternative stock exchange market - NewConnect which is a place for new, small and innovative companies with perspectives for fast future growth. In 2009 WSE founded the CATALYST market which is a WSE Bond Market. It is important to say that WSE is still a national company in which $98,8 \%$ of shares is held by State Treasury.

\section{B. Crisis impact}

Polish Stock Market Exchange is highly correlated with global capital markets. Besides the change of time which is a result of different time zones, WSE concentrates the foreign capital. The mood of international investors is very important then. Stock indices fall in New York may generate losses in WSE. However the fundamentals may differ but the moods of investors are the same. 
In 2008 Polish GDP was one of the highest in Europe and World as a whole. Polish economy grew by 5\%. The prognosis where even higher but American mortgage crisis and stock market fall revised this number. Stock Market Capitalization amount felt down from 144,323 millions of Euros in 2007 to only 65,178 millions of Euros in 2008 [European ... 2007 and 2008].

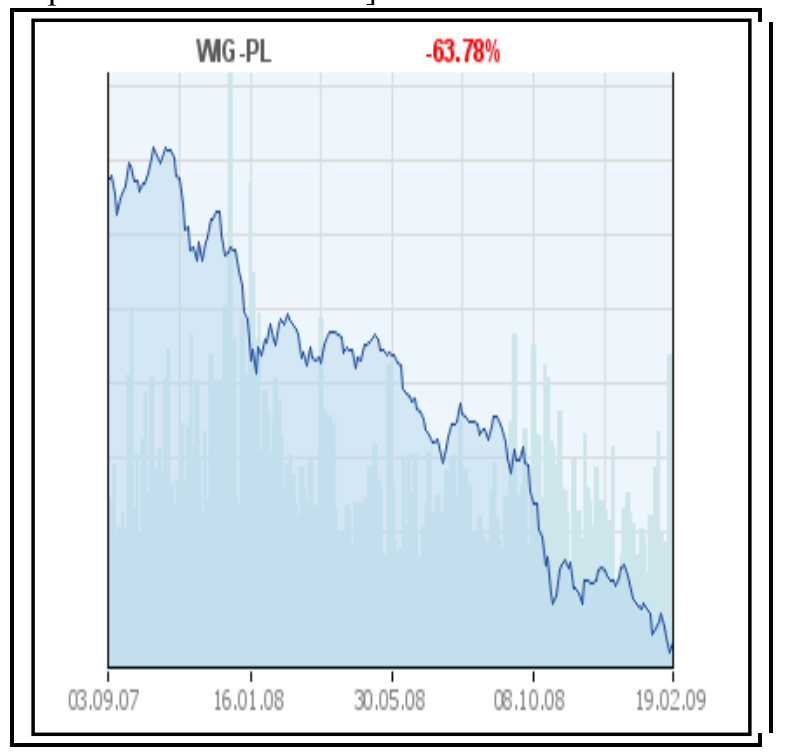

Source: Own elaboration.

Fig. 1: Main WSE index fall during the global crisis.

Capital market can be used a special tool for real economy prognosis. The movements on stock markets are always in advance of real companies situation. The fall which began in September 2007 took place in real economy in 2009. Strong Polish economy fundamentals and high level of GDP growth in 2008 helped WSE to reduce losses. It more than likely that in 2009 Polish GDP will be about $+1 \%$. This result may place Poland on a higher place in economy growth in Europe. Last European Commission's prognosis of GDP for GDP in 2009 estimated Poland in first place with $+1,1 \%$ growth [European Commision..., 2009].

It is important to underline that in Poland many companies are waiting until the crisis will finish to start their new development step on the Stock Market. In 2007 WSE was listing 375 companies, in 2008 it was 458 companies. This is the result of introduction alternative stock exchange market NewConnect. It was created at the end of Stock Market growth in 2007. It was very good time for new emissions. However, current situation of NewConnect is difficult because of its liquidity. Low level of foreign orders, lower employment, holding current investments due to the crisis, lower profits or non-profitable currencies exchange are only few causes of lower production level in NewConnect companies. In two year history, two first bankruptcy had place. This shows how dangerous the investments on alternative stock markets may be for not experienced investors.

The bond market Catalyst was launched on 30 September 2009. It operates on transaction platforms of the Warsaw Stock Exchange and BondSpot. The creation of a public market of municipal and corporate bonds under the Warsaw Stock Exchange brand gives local governments and companies a new opportunity of raising inexpensive capital for necessary investments. It makes issuers more reliable to investors and contractors and can work as a great marketing tool to promote an issue of bonds as well as the issuer: a municipality, a district, or a company [Kaszuba, The phenomenon... 2009].

Launching new markets in global crisis situation shows the strength of Polish Stock Exchange Market.

\section{AUSTRIAN WIENER BÖRSE AG}

\section{A. History}

Austrian Stock Exchange was founded in 1771 by Marie Therese. In the early years of its existence it was a place of bonds, bills of exchange and foreign currencies trade. Only chosen official brokers were responsible for the trade process and only they have the permission to charge the trade operations. First securities listing was made in 1881, the issuer was National Bank of Austria. Thanks to political and economic strong position in Europe, Austrian Stock Exchange become recognisable very fast.

Fast Austrian economy development and speculative trade in XIX century caused a big slump in 1873 - almost $90 \%$ of companies went bankrupt. First World War had great impact in Austrian capital market and until 1960s it was a place almost only for bonds trade. In 1989 new system PATS was introduced which made the market more attractive for foreign investors. The great change was made in 1999, when the new electronic system -Xetra was implemented which made the trade much easier for investors [Ziarko-Siwek, 2008, pp. 293-294].

\section{B. Crisis impact}

Due to geographical location and close economic relations with Germany and Eastern and Central Europe countries Austria was profiting from its good economic situation. Global crisis stopped this natural symbiosis. It is said in prognosis that individual consumption will be $1,5 \%$ reduced and investments for 4,6\%. Austria could easily fastened the exportation to Germany (bigger Austrian trade partner).

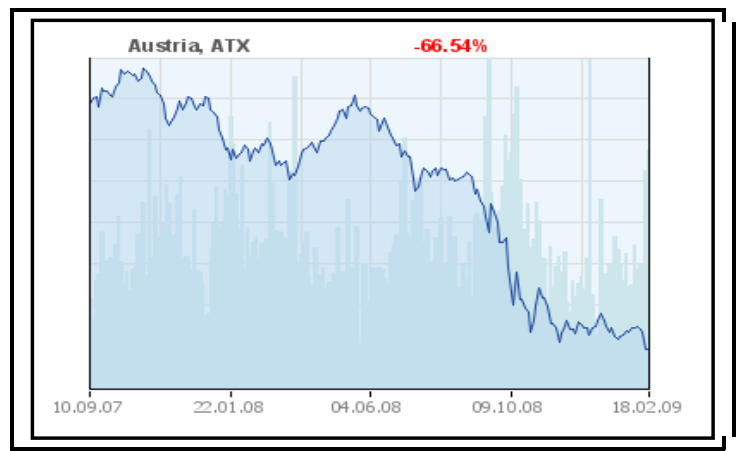

Source: Own elaboration.

Fig. 2. Main Austrian Stock Exchange index fall during the global crisis.

Moreover it could take profit from Eastern and Central Europe companies credits lending's. Global crisis revised these plans. The prognosis about German economy are not positive and generate $4-5 \%$ reduction of GDP. For Austrian economy which is highly dependable from Germany there is 
no worse information.

First months of 2009 are about to confirm difficult situation in Austria. In January and February Austrian exportation was reduced for $20 \%$. This is the greatest fall since in this country since The World War II. Serious problem for Austrian Economy has also engagement of Austrian banks into credit loaning to Central and Eastern European companies for approximately 230 billion Euros. These credits affect even $70 \%$ of Austrian GDP. In consequence Austrian Stock Exchange had noted big reduction on bank securities. This difficult situation affected also limited credit loaning even for Austrian customers.

Stock Market Capitalization amount felt down from 161,731 millions of Euros in 2007 to only 54,752 millions of Euros in 2008 [European... 2007 and 2008]. Austrian Government took many decisions and adopted certain procedures to reduce the impact of global crisis into economy The most important is 100 billion Euros governmental help for Austrian banks. Government plans also to intensify the Research and Development projects and infrastructure investments.

\section{HuNGARIAN BUDAPESTI ÉRTÉKTŐZDSE RT. (BET)}

\section{A. History}

Hungary was the first country from the Communist Bloc which reactivated capital market. In 1990, in only two weeks after the first free elections the first step of market liberalization was made. There were 41 shareholders including banks, brokerage houses, financial institutions and National Bank of Hungary. In 1995 the listings of main index BUX was launched. In 2001 new electronic system was implemented, which gave the possibility to make trade through the Internet. Dotcom crisis caused the large architecture changes in Hungarian Stock Exchange. In 2005 the fusion between Budapest Stock Exchange (BET) and Budapest Commodity Exchange (BAT) took place. It is important to say that Stock Exchange in Budapest is taking part in many international projects with Czech, Slovenian, and Polish Stock Exchange Markets.

\section{B. Crisis impact}

Global crisis had a bigger impact in Hungary in a view for European emerging markets. Enormous fall on Hungarian currency - forint caused very serious problems. Hungarian Stock Exchange Stock Index felt down for more than $11 \%$ in 09.09.2008. As a result Stock Exchange in Budapest was closed because of the loss of liquidity. Hungarian government and National Bank of Hungary is consequently informing about strong fundamentals of Hungarian economy. However, speculative foreign capital, budget deficit and deficit on current account are the bigger problems of Hungarians. Current account balance is highly dependable on foreign investments.

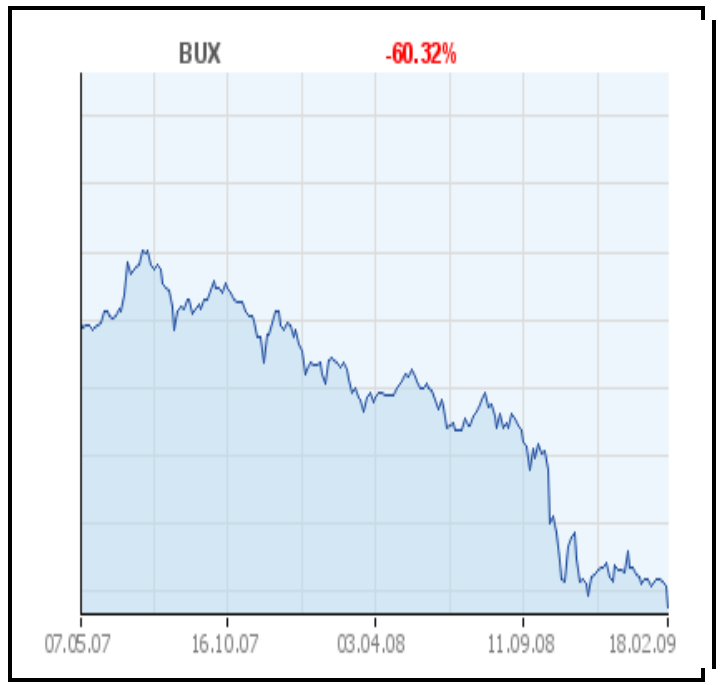

Source: Own elaboration

Fig. 3. Main Hungarian Stock Exchange index fall during the global crisis.

Hungarian government set up many procedures to protect the national economy but they were not efficient. Stock Market Capitalization amount felt down from 31,528 millions of Euros in 2007 to only 13,326 millions of Euros in 2008 [European... 2007 and 2008]. Ii is important to underline the impact of crisis in October 2008. Main Stock Exchange index - BUX had lost almost $30 \%$ in only two week time period. There were no chances for government announcements of budget deficit reduction. Worried foreign investors had immediately stopped their investments in Budapest. In the effect International Monetary Fund (IMF) helped Hungarian. After financial aid from IMF Hungarian forint value raised.

Hungarian crisis situation is more complicated than in i.e. Poland or Austria. It started in 2006, but it roots are even in 2000-2001. Political impact was very big for Hungarian. Election in 2002 caused the governmental money hand out. Public finances went in very bad condition. Prime Minister Ferenc Gyurcsany had lied to Hungarians during the elections and said to use fixed budget statistics during elections and Hungary needs to implement cautious reforms. This situation caused great disturbance on the streets. In two years he reduced huge, almost $10 \%$ budget deficit to $3 \%$ (which was ideal for convergence Maastricht criteria for Euro-zone).

When crisis became in United States in America, analysts started to focus on emerging markets and type the weak links. In European region the worst situation was in Hungary. Foreign investor's reaction was very fast and they pull out all their money from Hungarian Stock Exchange. The final call came from household economy. Hungarians had large credits in Swiss francs. Changes on currency market caused serious problems with credits repayments. Hungarian example shows that political stability is very important argument for development of emerging markets which can have even bigger impact that global crisis itself.

\section{EAST AND CENTRAL EUROPEAN FINANCIAL INTEGRATION HYPOTHESIS}

East and Central European Stock Exchanges can and 
should be compared to the global Stock Exchange Markets as well as to the Regional Stock Exchange Markets such as Nasdaq OMX Group. One national market cannot be compared to large European Stock Exchanges. There are several barriers such as market history or finally market development differences. None of Stock Exchanges in post-soviet countries cannot be compared with global financial market. But if compared as a whole, several conclusions can be made (see Table 1.)

Market capitalization of every Stock Exchange cannot be compared to amount presented by Euronext or Nasdaq OMX Group. However, the comparison of number of listed companies is very interesting. It can be seen that four countries can start to compete with largest European markets. Moreover, lower capitalization level can be easily described with lower countries development level. It is important to add that post-communist countries are the emerging markets. In my opinion it is interesting to characterize also a Notional Turnover on Derivatives in 2008. Amount of 142.832 million euro is almost only $15 \%$ of the Notional Turnover on the European Stock Exchange. This signify the maturity of Stock Exchange and very short modern history of capital market.

\section{CONCLUSION}

Polish economy has strong fundamentals and the impact of crisis was only caused by moods of foreign investors. It is important to underline the impact of one's of the oldest bank in United States of America - Lehman Brothers. Inexistence in day after one of the banks in financial market began the domino's effect. Central and Eastern Europe is often forgotten by foreign investors because of its geographical location. Poland, Austrian or Hungary as a part of emerging markets are playing very big role in global capital market. It is important to underline that foreign investors doesn't make any changes for investments in Poland or Hungarian. The same decisions are made for the whole region. Poland, Czech Republic or Hungarian Stock Exchanges roles may be compared to the role of Small and Medium Enterprises (SMEs) in national economies. Small markets can develop much faster, the rates of return may be also much higher. However it can't be forgotten that such markets as WSE generates also higher level risk. But if compared with fundamental analysis of market, global crisis will not affect these types of investments in long term. Moreover, emerging markets already gave high rate of return in only 6-month period.

In the European area it is noticed a disappearance of regional stock exchanges in favour of capital market integration. American Stock Exchange was integrated with European last years. In Europe EURONEXT Stock Exchange concentrates stock exchanges from several countries, including France, Belgium, Netherlands, Portugal and United Kingdom. The last advantage is introduction of one European currency - euro which eliminated problems with currency exchange. Stock Exchange Market Development is a factor of increase information effectiveness. It is important to mark-the-market and mark the correct securities price, which leads to the raise of market transparency and trust of investors to the stock exchange market.

In my opinion the future integration of European Union is unavoidable. It is also very unlike that the old 15 members of the EU separate again into smaller Union. Nowadays freedom in people, capital, goods, services is set. Future society must expect more and natural further step financial integration. Creation of integrated Eastern and Central European Stock Exchange Market would make a natural concurrence for financial centre in London and get a unique identity in global world. It is important to say that all these countries use very similar technical instruments. Furthermore it is essential to underline that Polish financial fall in compared time was lighter than in Austria but deep financial and political problems in Hungary are placing Poland as a leader of emerging markets in Eastern and Central Europe.

\section{REFERENCES}

[1] European Commission Report, Autumn forecast 2009-2011: EU economy on the road to a gradual recovery, 2009.

[2] European Exchange Report 2007, Federation of European Securities Exchanges, 2008.

[3] European Exchange Report 2008, Federation of European Secutities Exchange, 2009.

[4] S. Kaszuba, The phenomenon of Warsaw Stock Exchange on Poland in global crisis situation, Torun, 2009.

[5] U. Ziarko-Siwek. Giełdy papierów wartościowych w Europie CeDeWu, 2008.

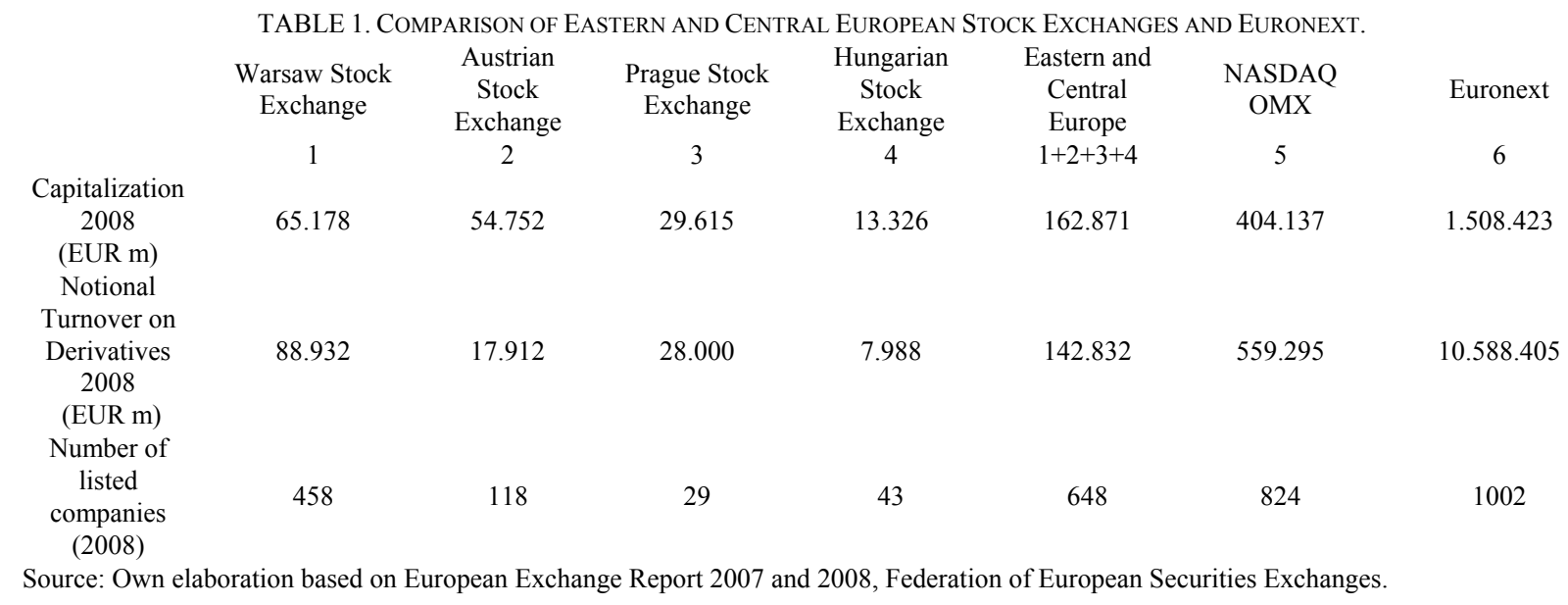

